\title{
ARABELLA RAUT THE EIGHTH
}

\author{
Karlo Antonio Galay David \\ Ateneo de Davao University \\ karlo.antonio.david@gmail.com
}

\begin{abstract}
About the Author
Karlo Antonio Galay David is a fourth generation resident of Kidapawan in North Cotabato. He has a Nick Joaquin Literary Award for fiction, a Palanca Award for drama, and his works in different languages have appeared in various local and national publication venues. He has an $A B$ in English from Ateneo de Davao University and an MA in Creative Writing from Silliman University. He was deployed to Taunggyi, Shan State, Myanmar by the Ateneo de Davao as a volunteer literature and research teacher, part of the pioneer deployment of the University's Cardoner Volunteer Program.
\end{abstract}


I was on the third day of the name's first misery on the streets of Kidapawan when I began to waver again. A child passed me by, eating deep fried chicken skin skewered on a barbecue stick. I had been starving for three days.

To keep myself going, I recounted the history of Arabella Raut. But this time, trying to see how I would pass on these miseries to the next holder of the name, how I would initiate her into it, and to the whole point of it.

Auntie Arabella the Sixth did it chronologically, from the starvation to her own impaling, and the second and fourth holders had no choice on their sequence. But yes, my first misery was easier, and it served as a good introduction. The next holder could then proceed chronologically from there.

'Listen then, 'day, and do as I say.' No, it was too coercive - how important it was to pass it on with the right wording. This shouldn't ever be imposed: my successor would have to take it up on her own. How did auntie Arabella say it? 'Listen, 'day... this is what I do, because like you I do not forget...' Yes, that was how she got me into it.

Then my first misery:

'This is what you do, 'day... Wander around, from town to town, and do this. You take flat stones of varying sizes and carefully stack them one on top of another, the biggest one at the bottom and with decreasing size as you go up. Carefully adjust the inclination of each stone so that every surface is perfectly flat before you add the next layer. Use little pebbles in between gaps to prevent it from tilting. Build this structure in a place where many people pass by, along a road perhaps, or in parks. When you complete it, feel the sense of accomplishment as you look at it - it will be eye-catching, and yet because it will be made of stones, how perfectly well it will blend with its environment. This will be the result and manifestation of your creative impulse -my Ate Ginamae's creative impulse, who like you felt the flatness of the stones in her fingers and realized too that something could be made from them. For yes, it will be her memorial - every one of these stacks you build will be a loving memorial to her and to all those who heard the call to build but who were destroyed, all those who have suffered, all those who have died.

'And it will be for all those we have given and from whom we inherit the name and burden of Arabella Raut.

Kritika Kultura 28 (2017): -362

(C) Ateneo de Manila University

<http://journals.ateneo.edu/ojs/kk/> 
'You will love them all, and you will build these stacks for them. And you will inherit their one hundred and ten years of suffering, and you will inherit this world that robbed them of the chance to live - after you finish these stacks, stand back. Watch as passing children or drunkards throw stones or piss at them.'

Yes, that would be a good beginning. Start with good feeling, and then dash it with reality. I could see how easy it was for Auntie Arabella the Sixth to get me to start it. The transition from that was very natural...

'People forget, 'day, but they never change.' How haunting her voice was when she told me that day, how empty her stare had been.

A group of students from the nearby Notre Dame of Kidapawan passed me by, completely ignoring my existence. Yes, people never change.

During the time of the Americans a tribal leader named Mangulayon killed the American governor of Davao, and the Americans set out to hunt down the assassin - ahuwes de kutsilyo, they called it. From Digos to Malita, in a span of several months they killed every living thing they saw, Tagacaolo, Manobo, Kalagan, cat, $\mathrm{dog}$, cow, goat. Nothing was left moving but for the severed limbs or gutted entrails swaying in the wind on the tree branches. In the uplands of Kibulan, Malalag, the Raut family, a poor Tagacaolo couple with two daughters, farmed root crops on the hills. Their eldest daughter was ten, named Arabella after the American missionary in Malalag who served midwife when she was born. The younger was named Najera, after some rich Kalagan princess from far away they heard had recently wedded a Tausug prince.

'The girls were named with the audacity with which their parents dreamed for them.'

The narrative was so well-phrased I was never able to forget it. All the holders of the name recited their narrations again and again to themselves and to each other over the century, polishing each one's phrasing,that they would be more effective both in initiating the next holder in and in keeping the current one at it.

Arabella was a restless girl. She grew up in the remote isolation of Kibulan, and was hungry for the world. So one day her father surrendered to her begging and sent her to Malalag to sell their meagre kamote harvest for the month.

She went down from Kibulanon the day the huwes de kutsilyo reached the town. 
Just at the rural outskirts of the poblacion she met the Americans, and they caught her and locked her up. She had not bled yet so the soldiers did not think of touching her, but they beat her when she wouldn't tell them what they wanted to know - she did not even know who Mangulayon was. When the men decided to go up to Kibulan they left her behind, battered and broken, inside the makeshift madre de cacao cage.

Worried because Arabella had not come home for two days, her father set out with his other daughter Najera to check on his missing daughter.

The two met the Americans on the way - when the father tried to resist, he was gunned down. A terrified Najera was able to escape, and, leaving her father's dead body she ran for her life downhill. After dashing madly through the thick woods, she stumbled upon her caged sister, by now starved and without water for two days. As she brought her sister out of the cage she could see smoke rising from the hills of Kibulan. Where their tiny hut and their neat rows of kamote tops could have been glimpsed, now there was only smouldering black. At the thought of what those white devils could do to their mother Najera lunged to go up, but her sister grabbed her arm and stopped her - 'no Jeray, it is too late. They would have killed her by now if they were done violating her. It is all too late.'

Malalag now razed, Najera helped her weak sister up, and the two made their way to Malita, Arabella demented with hunger, Najera bleeding in the feet from walking in the wilderness. They did not speak in the days that it took them to walk, but Najera instinctively knew that if they were to live they must reach Malita.

But the settlers of Malita had heard of Mangulayon's deed, and while in better days they were at best tolerant of the lumad, their tolerance turned to wariness after the incident - to help the natives might cause the Americans to suspect they were collaborating with native resistance.

'For this is how people are, 'day', the narrative went as Auntie Arabella the Sixth had recited it. 'This is how they are. Why risk the trouble, when they would get neither practical reward nor divine blessing from helping poor pagans?'

And so like many Tagacaolos and Manobos descending from the razed hillsides, Arabella and Najera starved in the streets of Malita, begging for food from people who would not spare a grain of rice. It was Najera who went around begging, Arabella only stared into nothingness without blinking since they arrived. She had had many dreams, and those with many dreams are shattered more easily by realities - the Americans had easily killed her inside. She died on the eighth day 
with eyes open, and only when her decaying body began smelling did the people of Malita began paying it attention.

'Now sit on the streets of any town, 'day', goes the narrative', and you will suffer the same. Sit there and do nothing, and you will starve. Not even a drop of water if it does not rain. Nobody will flock to help you.It is not human nature to help without being asked, and it most certainly isn't when nothing good comes out of helping. Begging is an active endeavour, you have to bother people and offer them rewards if you want them to help you - and never condescend to beg.'

The first misery is not foolproof, that much I can say. Even if you just sit there, people do sometimes give. In the seventeen times I've done this, three people gave me something without being asked: an old lady in Mlang gave half a bibingka; a little boy in GenSan threw me seventy-five centavos; and a teenager in Marbel gave five pesos.

But it sinks in all the more because these are exceptions. Seeing people walk by for eight days while you starve, living their lives as if nobody was dying right in front of them. The most you could hope for was to be an excuse for someone to assume the flattering appearance of generosity.

On the noon of my eighth day on the streets of Kidapawan I stood up and shuffled weakly towards the city's Mega Market.

I approached a fruit stand and asked to buy a kilo of mangoes. In hand was an ancient coin purse made of woven rattan fibre - Arabella's purse, where her father put the income from their kamote. It was the only thing left of her. Najera had taken it with her and never lost it, and every holder of the name has used it since.

The vendor's scepticism was dispelled when I took out a five hundred peso bill from it, handed the money to her, and told her to keep the change.

Mangoes in hand I inched my way to the Apo Sandawa Subdivision on the other end of the city - the walk took half the day. I had rented a small house there for the month.

There I broke the starvation with the mangoes. I ate them without even bothering to slice them, biting right through the skin.

The feeling of life slowly creeping back in as you absorbed the nourishment and moisture from the mangoes was revolting. Life had a sickening watery sweetness with a tinge of bitterness to it. 
After her sister died Najera too had gorged on the mangoes she stole from the fruit stalls of Malita to stay alive. She could not dare steal while Arabella lived - on the streets of Malitashe had felt her proud sister would not allow her to be as defiled as the world, even if it meant they starved to death. When Arabella died Najera felt like a rat freed from its trap, and she scurried away to live, and knowing she could do nothing with it, she left behind her sister's rotting body. She stole fruits from stalls and money from pockets, and with the little she was able to gather she made her way to the city of Davao to find a life there.

She would only return to Malita after twenty years, by then the adopted daughter of a wealthy old American couple with a hardware store in Oyangguren Street. They had picked her up as she wandered the streets of Davao, fed her, clothed her, put a roof over her head, schooled her, tried their best to raise her as their own daughter, and when they died left everything they owned to her. They loved her, and she loved them back. They tried to heal her wounds. She loved them for trying.

When the couple had asked her what her name was, she was choking with guilt and bitterness and resentment. Her sister had died because the people around could not be bothered to help, and she herself could not even bury her. And so she decided to hide from the world, to live hiding her truth and, in refusing to live as herself, she took the burden of living and suffering for her sister. She answered that her name was Arabella Raut.

She would return to Malita every year to starve herself on the streets for eight days, and she would do it again and again in different towns and cities for the rest of her life, always keeping palpable for herself what it meant to be at this world's capricious mercy.

Thus began the Arabella Raut line of mourners.

\section{II}

It's all about appearances, really. And maintaining the right appearance is part of the skills one Arabella Raut passed on to the next. One of the few things in this house I rented was a full body mirror, and from it I could see myself - hair dishevelled and dry, face blackened with smears of soot and dust, clothes as tattered and stained as rags. I could hardly recognize myself.

Auntie Arabella the Sixth thought me how to assume the appearance of a palaboy when starving in the streets. 'It was Manang Arabella the Fourth who came before 
me who developed these techniques,' she said. 'The right balance of soot and dust, 'day, and use your spit to get the right consistency. Don't smear it too thick or too spread out, a few streaks will do for a natural look... comb your hair down to the scalp so the hair will look dishevelled, and add egg whites to make it look dry... Set aside some rags to wear, and use it to clean shoes or window panes so it really gets the rag-like look...'

After finishing the mangoes, I cooked myself some lugaw. Then, after a few hours of recovering from the hunger, I showered - I had not bathed in over a week. After showering I blow-dried, put on a white camisole and a pair of fitting leggings, a deep red blazer, some foundation, lipstick, and mascara. Then I combed my hair, evening out the brown waves with some leave on and combing the bangs in a twirl.

Slightly old fashioned but beautiful - for over a century this was how Arabella Raut had looked like.

After packing the little that I brought to Kidapawan I put the valise on the backseat of the car, locked all the doors to the house, and began driving to Davao.

Kidapawan had changed a lot since I passed by it for the very first time. Even back then it was always the urban center of North Cotabato, a syudad that was not too steep to dream for. But it was much quieter, more rural - the first time I was here was when Auntie Arabella took me from Kabacan, and from the car's window I could hardly believe the greenery of Amas was already part of the city my father always talked about. Now there were fewer and fewer remote areas. The NPAs and the Moro insurgents must be finding it increasingly difficult to hide.

Whenever I was Cotabato-bound, I always stopped by Makilala on the way back. I would stop by at the public market to buy a bouquet of white chrysanthemums before heading to the farm in Concepcion, where since the end of the World War Arabella Raut had owned a few hectares of agricultural land.

One had to pass by half an hour of coconut and rambutan groves before reaching the farm. The start of a cacao plantation indicated I had arrived, and as I reached a small old house in the middle of the cacao trees a few farmhands approached to greet me. These hands were from Arakan and Libungan - like all my employees they were hired when I took the name, and when I pass on the name they will be replaced too.

In the house, Romeo the foreman gave me a breakdown of the last month's sales as we drank the tablea his wife had made for us. It was Auntie Arabella the Sixth 
who thought of starting cacao here (when she took over the land was not farmed), and as expected the global shortage made it a very profitable decision.

I remarked that the house needed repair, and told Romeo I was going to send people from Davao to repair it. This home was pre-war after all, and it had not been restored since the fifties. The capiz-shell windows were missing a few cells, and it seemed like leaking from the roof occurred often. Romeo had been living in the house with his family, but seemed to pay little attention to its care.

After giving him some final instructions, I went out and walked further into the cacao grove. In the middle of the plantation was a large acacia tree.

The Tagalog Don Filemon Segovia planted it along with other trees shortly after he arrived here with his young, pregnant wife Lucrezia in the nineteen-thirties, part of the American-encouraged wave of migrants into Mindanao. He used the trees as a hedge to mark the bit of vacant land he claimed for himself. He would later earn enough money and influence in town to get hold of a title, and he would also get to buy the adjacent lots from the Ilonggos who claimed it. The trees of the consequently vestigial hedge were felled over the years for timber and firewood, but this tree was spared by chance.

Don Filemon would never have imagined that, under the Japanese occupation, anti-Japanese guerrillas would gun him down tied up to its trunk.

I put the bouquet at the feet of the tree. Chrysanthemums were Lucrezia Segovia's favourite flowers.

The young Segovia daughter Helena never really understood why - they were dull and had that stuffy smell of prolonged wakes. But she was hardly surprised - though quite young her mother was prudish to the point of being stuffy herself, a grand Maria Clara all too conscious of her dignity. She would always chastise Helena for being too friendly with the farmhands' children, or for sounding too Cebuano or Ilonggo at the dining table.

Stuffy, but she was never dull - Doña Lucrezia was, in spite of her being a mother, still one of the most beautiful women in the area, rivalling the local pageant winners in Lamitan, or even the more prestigious ones from Kidapawan nearby. There was no matching that blaze of intensity that hid behind her stuffiness, that flaming hunger for all the wonders around her, only made more potent by her holding it back. She was near her thirties and yet she burned with a vigour that made any woman in her teens pale. The men of Makilala would get a glimpse of it whenever they were introduced to her: a sudden spark in her eyes would flare

Kritika Kultura 28 (2017): -362 
up as she devoured the sight of anyone and anything new. The men would forget they were talking to a wife and mother, and would fall in love at once, but they would never see that spark again. Even the Japanese soldiers during the World War could hardly keep themselves from showing disrespect before their local landlord friend's wife.

Come to think of it, that beauty and fame were ultimately her undoing. After taking over their land and killing her husband, the guerrillas raped her repeatedly at the foot of the tree. Good punishment, they jeered, for the wife of a collaborator. When the Japanese authorities finally went to check on Don Filemon, Lucrezia's body was dangling from the tree by a carabao's rope.

Helena counted thirty-five men who raped her mother, the last one she saw doing it from behind as the others made her crawl by dragging her by the neck with that rope. Helena was just eight, and was always tomboyish, homely and tan from all the playing under the sun. They were planning to just kill her too when someone suggested having a taste of the famous Doña Lucrezia Segovia, and their libidos distracted them even as she screamed for her mother to be spared. So she saw it all, each one of them, from the scrawny teenage guerrilla who was one of their farmhands' sons with barely any pubic hair, to that porky old man from Kisante who farted while he violated Lucrezia.

The sight of it had shocked Helena to a calm dementedness, and she found herself thinking rationally. She rubbed the rope with which they tied her hands behind her against the steel side of a nearby tractor and, waiting until all of the men were completely preoccupied by the rape, she ran for her life quietly. She ran with that strangely light burden of hopelessness weighing her down - there was no use even calling for help, by the time she would meet the nearest people around, the guerillas would have killed her mother already. Nobody even seemed to have noticed she was gone, for even until she reached the highway after three hours of running through coconut and rambutan groves, nobody pursued her.

Exhausted and bleeding in the feet from the rocks and brambles of the escape, she walked even further to Lamitan in what is now Makilala's poblacion, where Najera, who had taken the name of Arabella Raut the Second and by then was already in her forties, was on her seventh day of starvation.

I was on the road, just exiting Bansalan and about to turn left on the forked road along Digos. I and Auntie Arabella the Sixth were starving here when I first learned about the other generations of the name.

Kritika Kultura 28 (2017): -362

(C) Ateneo de Manila University

$<$ http://journals.ateneo.edu/ojs/kk/> 
It was really Helena who developed the line. When Arabella Raut the Second (Najera) took her in, she had no intention of passing on her misery to this girl. But some years after the war ended, Helena asked that they go back to Makilala to find out what happened to Lucrezia and their land.

They learned from the local government that the estate was currently owned by the municipio and in the market, since nobody knew where the lost daughter Helena was (she kept her identity a secret on getting there) and the Segovias left no other heir. When they went to the area they found the house looted but still standing, all Don Filemon's rambutan trees chopped down or burned, but the acacia tree still standing. They learned from the locals how the men had hanged the landowner's wife from the tree after getting tired of her before leaving the estate. After the war these men had returned to their normal lives (the teen guerrilla apparently joined the army, and the old man was a municipal councillor and had died recently), and nothing more was said and done about the matter. The locals buried the Segovia couple, but they forgot where they did so.

When they reached the tree, Auntie Arabella the Sixth had told me, Helena fell silent for a long time. Then suddenly, she asked Arabella the Second (Najera) why she starved herself on the streets. She had never spoken about it, but this time Arabella the Second talked about her own past: how she was named Najera, about the huwes de kutsilyo in Kibulan during the time of the Americans, and about Arabella her sister.

When Arabella the Second (Najera) had finished, Helena answered with hopeless resolution that the woman raped and killed on the tree too was Arabella Raut - and she, Helena, was Lucrezia Segovia, and when Arabella (Najera) dies she would take on the name of Arabella Raut the Fourth and live on to suffer the world for them all.

So we had posthumously given the name to those that died since - that made Helena Arabella Raut the Fourth, and it made me Arabella Raut the Eighth. That also started the tradition of using our deceased loved one's name before taking Arabella Raut: I took on Ate's name, Ginamae Balbuena, before Auntie Arabella the Sixth passed the name to me.

It had turned dark by the time I reached Sta Cruz. I looked for a corner in which to park the car, and on the way I saw three middle-aged men drinking in front of a sari-sari store.

They were perfect for the next misery.

Kritika Kultura 28 (2017): -362

(C) Ateneo de Manila University

$<$ http://journals.ateneo.edu/ojs/kk/> 
Of all the miseries that came with the name this one demanded the most skill. It took me years of practicing just the right look in front of the mirror with Auntie Arabella the Sixth before I was able to do it.

'Day, men are animals. That was what Manang Arabella the Fourth learned when she was just eight. They are animals, and with just the smallest sign of order falling apart, they begin revealing their true nature. Give them the slightest motivation and they will ruin your life just to please themselves for a few minutes. She learned this in war, but when she took on the name she set about seeing for herself if this was true in peacetime, and I've been doing it decades later and it's still true. Even with me at this age. They are animals. Today, you too will learn how to do it.'

After parking, I took off my blazer, my slacks, my heels and my stockings, put on very short yellow shorts, tied my hair up, and put on a pair of Havaianas. My skin was glowing in the Sta. Cruz night as I stepped out of the car.

This misery was created because Helena was a curious girl, even after Arabella the Second (Najera) took her in. As a girl in Makilala she always played pranks on the farm hands' children to see how they would react. When Arabella the Second took her to Davao, she would peel off her scabs and pour different liquids on the reopened wound - alcohol, cooking oil, gasoline - to feel how it would hurt.

Before she was swallowed by her misery she could be a cheerful girl in Davao. As a teenager, in between her bouts of violent depression, she enjoyed dressing up, wearing wildly different colours of lipstick, having her hair cut or styled in very different manners. She would make it a game to make her appearance so different that people - the employees and regular customers in the hardware, her classmates in Sta. Ana when she was still going to school - would not recognize her. Nightmares of seeing her mother raped repeatedly would later extinguish all the cheerfulness, but her tendency to experiment persisted.

It was her who made the miseries about testing people - the misery she left behind showed just that. Arabella the Second starved to simply remember the misery. When Helena became Arabella the Fourth, she made it into the ritual to test the world, making the memorial dimension of it more intense as it revealed how little the world has actually improved.

And it was her, with her careful attention to detail, who determined that it was all in the appearances.

'Walk slowly, lightly grinding your shoulders and your hips in alternate directions so that your left shoulder moves forward with your right foot, and vice versa. No, not

Kritika Kultura 28 (2017): -362 
like that, like this... Yes, like that... Never overdo it, you must keep it natural. Keep your head straight, slightly looking down...'

As I approached them, the group of drinking men fell silent, throwing each other meaningful looks - like animals on alert for a hunt. One of them was completely bald, another had many missing teeth, the other was cross-eyed, and all of them had large bellies. Then, when I got slightly past them, I turned my head around a bit and gave them the look, and they perked up.

'Be deceitful, 'day, but never lie. Manang Arabella the Fourth learned that a look of disgust from a woman, if subtle enough, looks seductive to men. The look is what's most important.Look at them as if you just saw a cockroach from afar-eyes half closed, lips pursed in a pouting grimace, then walk away at a slightly slower pace. Yes, like that...'

I did so, walking towards the nearby abandoned purok hut, which covered in weeds and overgrown trees was shrouded in darkness.

Before I knew it the three men were behind me, and they gently dragged me into the purok hut. I had no time to waver.

'Struggle, but in a way that looks like pleasured thrashing. It will not be difficult, the thought of this disgusting stranger suddenly forcing himself on you is enough to paralyze and weaken you. It will be horrible every single time you do it, but do it.Take it all in, the full putridity of it. For the memory of all the holders of the name, let the barbarity of mankind penetrate you'.

I'm sure Arabella Raut the Fourth (Helena) took years to polish that phrasing too.

Two of them did it to me at a time while the other kept watch, and they took turns at it. This kept them at it and the whole thing lasted over an hour. All throughout, my mouth was stuffed by hand or manhood, stifling me from screaming (men seemed to love stuffing things into women's mouths). At some point they took me both ways (one man's hand still in my mouth), I was on top of the bald man while the toothless one came from behind. They both reeked of Tuba wine, though the bald man's breath smelled like banana leaves on spoiled kutsinta. Unable to restrain himself the cross-eyed one left his watch, joined in, and stuffed himself into my mouth. I could hardly struggle, when I fought back it only seemed like I was flailing in pleasure. 
The bastards let it all out inside me, before simply walking away. Usually the man (or the men) would throw me a few bills after - compensation, as if I was some whore - but apparently these men just thought I was in it for the good time.

The most I've experienced was four men, who raped me on some back alley in Butuan. They didn't pay me either, but one of them seemed to have had syphilis. I could afford treatment, but those were tricycle drivers who couldn't, so I relished the schadenfreude after that. That was three years ago, and because it was some time ago this was more harrowing than it should have been.

I inched my way back to the car, sore all over. Inside the car I sat trembling for over an hour, letting it all sink in.

A lump in my throat was rearing to burst out, but I held it in, clenching the steering wheel. No, letting it out will reduce the trauma of it, I must bottle it in and let it spread inside.

This was how I knew sex - the first time I did this misery, my first time, was under a flyover with an old taxi driver in Davao. The idea of doing it for pleasure was unimaginable. How could a woman find being pierced by some barbarian through her guts to let out his bodily fluids pleasurable? Every time I drove past some man on the streets after doing this misery, I resisted the urge to turn the wheel and just hit him.

I reached the house at nine in the evening greeted by Bantay's barking. In my room I took the pill bottle from the first aid kit and swallowed a pill before showering. I showered until all the smell of Tuba and semen came off. I dried my hair and body with a towel gently, still sore from the ordeal, and exhausted, I fell asleep naked on my bed.

I slept uneasily. I dreamt of Lucrezia Segovia being raped beneath that tree, her screams mixing with the guerrillas' laughter. Then her screams became faint and far away, becoming those of Najera's mother, and I dreamt about the hills of Kibulan charred to smouldering black. Then the fires burst, and I dreamt about Ate Ginamae, standing helpless in the middle of the burning corn fields. I woke up gasping for breath, breaking into a cold sweat. Bantay was looking at me from down the bed.

It was dawn. I had taken the name of Arabella Raut, and I inherited her nightmares with it. 


\section{III}

The past holders of the name had done the work of refining the way by which the proclivities of the name were passed on. All that was left for me to do was to develop the pedagogy of my own miseries and do the actual transmission.

Of course, there was more to being Arabella Raut than just the narratives and the miseries. She had to deal with the practical matters too.

I was having breakfast, going over some paperwork, while Gang-Gang the maid was frying some fish. Bantay was looking at me from down the table, hungrily expecting the next bit of table scrap.

Like all holders of the name I first relished the sudden luxury of wealth when I was taken in, but when the past would become more haunting by the day I was led to take on the name and all its miseries along with my own, and since then I've acquired this austerity - sumptuousness would be sickening if one lived a life in which the world's misery was made constantly palpable. My coffee was made of burnt corn Gang-Gang had brought from her bukid in Baganga, bitter, no milk, and no sugar. My food was always cold and plain. Since taking over the name I'd forgotten what it was like to enjoy what I was eating.

Sales of the convenience store were up in the last quarter, and there was another company from France seeking supplies of raw cacao beans. The rent from the tenants in the building in Oyangguren was also in, and a lawyer interested in renting the last vacant unit had sent in a letter of interest.

I remembered the first time I met a client. I was still Ginamae Balbuena, but Auntie Arabella the Sixth was beginning the transition already. I had began taking on the Arabella Raut appearance, and I was made to meet new clients, letting them assume I was Arabella Raut. Auntie Arabella the Sixth continued to meet the older clients and business partners until new personnel were sent to us, in which case I took over. The same was done with the employees in the convenience store, the office, and the farms, although that came later, as Auntie Arabella the Sixth let me hire new employees when I had taken over completely. Like that, bit by bit, I assumed her identity, and she began appearing in public less and less.

When I had documents updated, banks and government offices had no problem believing it was a typographical error on their part - there was no way I was born in 1961. I had earlier sent new photos discreetly under the pretext of updating my profiles. 
The arrangement actually proved advantageous for the business over the century, as we never had to pay inheritance taxes.

Auntie Arabella the Sixth was there to facilitate the transition, so I guess I had to help the next holder take over too. It was all awfully complicated, could I do it? I had only held the name for seven years, I still had much time to practice.

A rooster crowed somewhere outside. Doña Vicenta subdivision was not a very neighbourly community, so we never had trouble dealing with neighbours. Arabella the Fourth (Helena) bought this house. Before that she had lived with Arabella the Second (Najera) on the second level of the hardware store in Oyangguren. It was barren, save for a few pieces of furniture, a large bookshelf in my room with all the books gathered since the American couple who adopted Arabella the Second, and some picture frames on the walls containing thank-you messages, with crude drawings in crayon, by the children of the orphanages and evacuation centers.

Much of the estate's income actually went to donations to orphanages and relief operations in war-torn areas in Mindanao. Arabella the Second (Najera) helped establish a charity to help the affected lumad communities during the American conquest, and it continued well into the Marcos era, helping the lumad displaced by the government-sponsored immigration from Luzon and Visayas. Later she and Arabella the Fourth (Helena) donated much to efforts to help survivors of the World War. From the Fifties Arabella the Fourth would go around Mindanao to remote towns, funding livelihood programs to help civilians affected by local insurgencies, and Auntie Arabella the Sixth funded the establishment of many orphanages. My contribution had been to fund the construction and maintenance of war memorials in Mindanao (many of which I visited regularly). For all its bloody history, this land had little by which to remember its tragedies...

All that needed a lot of money, but for over a century we had done it. Admittedly Auntie Arabella the Sixth left me a more difficult estate to manage than what she had inherited. When she took over, all she had to look after was a building in Oyangguren with a hardware store and some renting tenants, and an unused patch of farmland in Makilala. She had more than doubled the estate's annual income when she took over, converting the unproductive hardware store into a convenience store, entering the cacao market, and investing in housing projects across Davao.

Auntie Arabella the Sixth. Of all the holders of the name so far she dwelled on suffering the most. 'It will hurt, 'day, but all humans will die eventually. We suffer to remember those who had suffered and had been forgotten, and like them death will be our relief...' 
I stood up and told Gang-Gang to prepare my valise again before I went to my room to bathe and change. She had grown accustomed to these unexplained departures of mine. She must have thought I was off to meet some lover.

I told her to make sure the knife and first aid kit were inside.

She opened the gate as I brought the car out into the road, Bantay wagging his tail to see me off. I gave her some final instructions from my opened car window before setting out for Tagum.

Auntie Arabella the Sixth was a remarkable woman. Most of the books in the bookshelf in my room had been hers - Dostoevsky, Turgenev, Hesse, Nietzsche, Mishima, Akutagawa. If Arabella the Second (Najera) allowed Arabella the Fourth (Helena) to be a normal young lady before she succumbed to the name, Arabella the Fourth allowed Auntie Arabella the Sixth to continue being a voracious reader when she took her in. At the age of twelve Auntie had managed to teach herself Russian and German.

'Leidenism', she called her own worldview.

'I remember my grandmother, 'day, as they decided to finally kill her. How sweetly she smiled. Finally, her suffering would be over. And that was when I realized that all of us were in the same situation, we had just grown accustomed to the pain. And it was stupid to grow accustomed to it because it will not last. Death should not be the end of bliss, it should be relief.

She was always a contemplative person, even at a young age. It was her who analyzed and reflected on how the two previous holders of the name went about with the miseries, Arabella the Second with mistrust and isolation, Arabella the Fourth with misanthropy.

And because she was contemplative like this, the world's absurd cruelty was also more palpable to her. Of all the holders of the name so far she was the one who succumbed to it soonest.

I reached Tagum, and I went further to its uninhabited outskirts, just where Braulio Dujali began. On reaching the foot of a low hill covered in cogon, I left the beaten track and made my way up.

It was into a patch of thick wild cogon like this that Auntie Arabella the Sixth and her grandmother Laylania escaped the Ilaga in 1971. Back then she was still Jamayra Mangadto, and she was hardly eight years old. 
Manili, in Carmen, North Cotabato, was very remote, so it was little surprise her father could not get proper medical attention when he fell victim to tuberculosis and died. She had already lost her mother when she was born, and at just two years old she was orphaned. Her grandparents, small time Maguindanaw sugarcane farmers, took care of her. They had raised her to be a devout Muslim, and when her grandmother taught her to read Arabic she devoured the Qur'an. She was the brightest girl in the masjid, and every child in their remote barrio admired her.

'I never knew her, 'day, but I know how the original Arabella Raut felt when the Americans demanded to know where that Mangulayon was.

'When the soldiers and the Ilaga arrived at the masjid in sitio Bual that day, they bickered with Hajji Yusof and demanded that we surrender someone named Enalang. We had no idea who Enalang was, though some of those from the sitio had heard of the name.

'When we heard gunshots, lolo took a peek outside and saw that they had shot Hajji Yusof. He told lola to take me and run for it, and after hesitating lola carried me away. On our way out she was hit by several bullets on the thigh and arms, but she kept running, carrying me.'

'We escaped into a field of wild cogon, and that was where she began to lose too much blood. I came down and helped her through the cogon, reaching the end of the field. We could hear gunshots, screams and explosions from the masjid, and I will never forget the smell of blood in the air.'

I had walked some distance away from the car, combing through the thick cogon around me. I cut the ones with the most woody stalks with the knife, cut the stalks to the length of a hand (forming eight pieces in all), then I sharpened the tips of each one.

'Then, just as we were about to enter the woods, a group of the men had caught up to us. Lola pushed me away, forcing me to hide behind a tree, as she fell to the ground.

'When they reached her, they jeered at her, kicking her and laughing. You would know that they were Ilaga because of the strings of human ears around their necks.'

As I saw the fibrous tip of each stalk I sharpened, I shuddered at the idea of it entering flesh. How could anyone even find it amusing to do this to other people? 
This was the misery I hesitated with most, but the hesitation made the misery all the more compelling.

With the knife I cut myself in the palms of the hand, in the upper arms, on the shoulder, on my thighs, and on the soles of my feet. Then, one wound at a time, I made Laylania Mangadto's memory palpable again...

'One of the men cut down some cogon as the others kicked her around. He was cutting the stalks into small pieces, sharpened the tips with his bolo, and, one by one, impaled them into lola's open wounds. I can still hear lola screaming. Then when all her wounds had been stuffed with cogon stalks, they made new cuts and impaled stalks into those...'

The car was some distance away, and I crawled towards its direction. Each time I clawed on my hands the cogon stalk dug deeper inside, the sharp cogon leaves also cutting my face. It took me half an hour to reach the car.

'Tuyom!' they jeered at her, but one of them mocked her because she had probably never even seen the sea yet, much less known what a sea urchin was, living this remotely inland. I could barely watch, but I was too worried about her to take my eyes off her. Then, when she was too weak to even thrash about in pain, one of them grabbed her by the hair and slit her throat, then they cut off her ears before they went back to the masjid. I just hid there behind that tree, trembling in fear, forgetting how to cry in horror. I envy your Ate Ginamae sometimes.'

'I hid there behind the tree, 'day, holding my breath - you know how difficult it is to hold your breath when all your body wants to do is sob your lungs out? But I held it in until they were far away, and I crawled, crawled away for my life.'

Jamayra took a day just to get to the nearest highway. On the road she passed out, and when she came to, a family on car from Liliongan found her and picked her up. They were on their way to Kabacan, and though they could not get her to speak a word about what had happened to her they guessed from the blood all over her that she was affected by another armed encounter. They left her in the evacuation center in Kabacan set up for those displaced by the clashes between government and insurgent forces. In the evacuation center Arabella Raut the Fourth (Helena) was helping distribute relief goods.

'I could not speak to people 'day because I felt I was defiled by death, that I reeked of it, and that if I talked about it I would just be defiling people's lives too. But when I saw Manang Arabella the Fourth, I sensed that she too had seen death, and that she 
was already used to its rancidity - her eyes were dead, as dead as my own. I found myself telling her what had happened.

'And she told me what I had told you 'day, when you first opened up to me'.

I had cleaned the cuts, put ointment, and wrapped them in bandages. Driving with my fingers on the steering wheel (if I used my palms they would bleed all over), I drove past Panabo into Panacan, remembering what she had said to me on the day we met.

'Then take my name 'day, and do what I do, because like you I do not forget...'

\section{IV}

I had scheduled to do my burning misery the next day. On my way from the office in Oyangguren I called the old farmer in Samal I contacted three weeks ago. He had finished the payag I had had built in the middle of the woods of Baranggay Tagpopongan the other day.

The farmer must be wondering what this woman was going to do with a payag in the middle of Samal. How eccentric I must have seemed.

Eccentricity. With all the problems the world had, people were more concerned with appearances. Ate Ginamae was brilliant, and yet the neighbourhood children in Dilangaoen picked on her for doing things they found weird. She liked gathering weeds and observing how different they were - she wanted to be a botanist. Some corn farmer's daughter in the isolated outskirts of Pikit wanting to be a botanist was already crazy enough. A manugbarang, they called her, gathering recados for the lana she was brewing. Then she liked to build those stacks of stones: she wanted to be a landscaper too, and she had the eye for it. The old people just told Tatay off, telling him his daughter was making punso.

People could be so shallow. And yet even their principles with appearances, you could buy. Pay them five hundred and they'd walk naked into a church.

I felt a slight pang as Bantay greeted me lovingly when I came back home. GangGang approached to ask if she was to cook lunch. I said she did not need to, then I told her to get me a lighter. 
Lighter and Bantay's leash in hand I stood by the car's open door, beckoning to Bantay to get in. He had never been in the car before, so he just stood there, confused. I nudged him gently into the passenger's seat, closed the door, and we set out for Samal.

On the way to Sasa Wharf I stopped by a gasoline station and bought a litter of diesel, having it dispensed in an old plastic container.

The sight of Davao Gulf made me feel uncomfortable. The sea always made me feel small, fragile, insignificant. On the barge, Bantay followed me cautiously to see the water.

Ate Ginamae never saw the sea. She wanted to see sand, seeing the contrast between white and black. She had no idea what zen gardens were but she thought of designing a garden with sand.

The teachers of Dilangaoen Central Elementary School warily acknowledged her intelligence, giving her the grades that she deserved but nothing more, never giving her the chance to participate in inter-school competitions. She spoke great English, but she never represented the school for oration events, and her spelling was impeccable, but she never even got to see a spelling bee.

Dalingaoen was mostly Muslim, but we were one of the few Bisaya Catholic families in the community. I grew up knowing only wariness between us and our neighbours - we, careful not to seem too arrogantly Filipino, they, careful not to reinforce the violent Muslim stereotype. Recognition for Ate Ginamae, who was bright in her own right, was the casualty. Auntie Arabella the Sixth said she envied what ate had done, Ate Ginamae would have envied how much her community loved her.

But she knew that if she was to thrive she had to look elsewhere. Without Nanay and Tatay knowing, she sent an application for a scholarship to a high school in Davao. She only told us when she got accepted.

Nanay was proud of course, but she was worried about accepting it. Where would Ate live in Davao? We had no relatives or acquaintances there, how could we afford rent? And how would she live there if we didn't have enough money to send her?

Ate was calm enough to realize this when she applied, but she still remained optimistic, that she could find a way. And Nanay and Tatay knew that their elder 
daughter always found a way. She even told me she'd find a place where she could bring our dog Bantay.

We were traversing the thick wilderness of Samal along a sandy road, Bantay looking out of the passenger's seat window. In a while we reached Tagpopongan, and after going further inland I spotted the farmer's hut.

His humble house looked just like ours - dirt floor, a wooden bench outside the makeshift door, roof made of nipa and walls of crudely woven sawali, dirt kitchen, and just two rooms, one for the parents and the other for the children.

Ate Ginamae was just itching to leave it. On the week after her graduation from elementary, she told us she found a solution. A convent near the school she applied to agreed to accept her as a maid. They even let her bring Bantay, as the older nuns needed a dog to amuse themselves with in between prayers. Everything was going so well for her.

And then the Estrada administration declared all-out war on the MILF.

I came down from the car, and the farmer greeted me timidly. His wife and children looked on from the house, nodding in greetings. I did not know their names, nor did I need to - I simply called the farmer 'nong.' I just saw him in the Bangkerohan market delivering mangoes, asked him where he was from, and hired him to build this payag outside his farm. Money silenced questions.

As gingerly as he came in Bantay came out of the car. Of the four Bantays I'd owned this was the most subdued.

The farmer, a middle aged man with a large belly, guided me though the thicket of wild bushes on the edge of his small mango plantation, Bantay trudging along behind me. The container of gasoline and the leash were in my hand.

At length we reached a light clearing, at the center of which the payag stood. It was tiny, about a fourth of the farmer's hut, with just one room as interior, and no floor. Its entrance was facing away from us, and its wall was made of even cruder sawali. As instructed it had a thick roof of nipa and pillars on the four corners made of coconut lumber.

To think people lived in buildings like this in a land constantly plagued by war how fragile life was in Mindanao.

Kritika Kultura 28 (2017): -362 
The farmer stayed where we stood as I approached the payag with Bantay. As expected the inside of the structure was empty.

I tied one end of the leash to the coconut pillar, then tied the other end to Bantay. He sat obediently as I gathered some of the dried brambles from the farmer's clearing the location. Then, I poured gasoline on the pile of brambles and all over the payag.

Tatay of course could not afford to buy gasoline. He had made the decision when we heard that some Moro forces were edging closer and closer to Dilangaoen. MNLF, MILF, Abu Sayyaf - it didn't matter, they were Muslim separatists with guns and we were Bisaya Catholics living within walls of sawali.

And suddenly, when we had heard gunfire, TTatay had to execute it hastily. It was noon, and we were having our lunch. Nanay rushed out of the house dragging us, and TTatay gathered a clump of dried corn stalks off the stove and set it on fire from the embers under the caldero. Going out, he began to set fire to our payag.

Our dog Bantay was stuck inside - he had been sleeping in one of the rooms, and was too scared of the gunshots to go out. I shouted out to Tatay as he ran towards us that Bantay was still there.

It did not matter, he said. Just run. I was frozen, so Nanay carried me away.

There was a curious look on the face of the farmer as I stood beside him looking at the fire. We could hear Bantay crying inside.

I gave him the three thousand pesos agreed upon, and he walked away, counting the bills, as Bantay's yelping grew louder and louder.

This was the third time I had done this, but it never ceased to revolt. Intense sadness condensed to horror, but a sense of powerlessness that would paralyze me. I was the Arabella Raut most prone to wavering, and I came up with this misery to keep me at it.

I had raised this Bantay for two years, seeing him grow from a playful askal puppy to the subdued but intelligent dog he had become. And then, just like that, he was dying. The farmer could have thought I was some crazy woman, but why bother when he could earn something out of not doing anything?

How little life mattered to people. Just as Tatay headed to follow us, he was shot in the back. Nanay and Ate screamed. An armed man came out of the woods

Kritika Kultura 28 (2017): -362 
behind the house - it seemed like he had just shot Tatay to know who was there, and looking at Tatay twitching on the ground he casually shot him in the head. He called in three more of his comrades out of the woods when NNanay dropped me and ran dementedly at them, shrieking in anger. I could hear the men cursing in Maguindanawon as they gunned her down too.

Ate Ginamae grabbed me by the arm and we ran into the cornfield, which was dry after the harvest. I did not understand at the time why but she had picked up NNanay's bag, ransacked it as we crossed the field, and when she got hold of Tatay's old lighter she threw away everything else.

At the edge of the cornfield we saw the men were halfway amidst the dry corn stalks. In no time they would catch up to us.

With a terrible determination in her eyes Ate Ginamae grabbed some of the dried corn stalks, set them alight with the lighter, and looked at me. "Go on, Gracelyn," she said, "head for Takipan, they must have an evacuation center there." I was numb at the sight of Bantay, TTatay, and NNanay dying, but I realized that I was about to lose her too, and I refused to leave. She insisted, almost angrily, and she kicked me out into the wilderness at the edge of the field.

Then she ran to the center of the field, setting everything around her on fire. It had not rained for weeks, so even the air was dry. Almost instantly, she disappeared into the sea of flames.

She was Arabella Raut the Seventh, and I took on the burden of living for her.

At home, I entered my room without supper and slept, exhausted. Again, I restrained the lump on my throat from bursting out. Bantay's absence was disquietingly palpable. Gang-Gang knew better than to ask where the dog went.

I had completed the full cycle again. As I began thinking of a good way to phrase the instructions to the burning misery, I slowly fell asleep and began dreaming.

\section{V}

This land had seen one war after another, spilling the blood of countless innocent people, and yet it had trouble remembering any of it. Indiscriminate exterminations, bloody insurgencies and counter-insurgencies, massacres, slaughters,rapes Mindanao continued to suffer, and as it suffered it continued to forget. 
But for over a century and a decade, we who had held the name of Arabella Raut remembered, and we continued to remember and relive the pain and misery of those who perished, and those who lived.

It may have been a bit too early, but I had been thinking of the next holder of the name ever since I took it. Thinking about how I'd pass the name and its miseries made me realize how I inherited an unspoken responsibility for this land - the responsibility to never forget.

But where was I to find the next holder?

Arabella the Fourth (Helena) and Auntie Arabella the Sixth set the precedent of finding their potential successors in evacuation centers. Not every refugee could take the name on, though - Auntie Arabella the Sixth said she interacted with at least seven war orphans with the aim of finding a successor before she stumbled upon me. People could be callous by nature; it took someone with a devastated sensitivity to bear the burden of the name.

On one rainy afternoon, I entered a coffee shop somewhere in downtown Davao's Matina area. The wifi at home was down, and I thought of looking up on the internet possible places where I could find the next holder. It was a quiet Sunday, and the coffee shop was empty of customers.

There were two baristas, but one was busy cleaning the bathroom, so the one on the counter entertained me.

He was young, fresh-looking, and he had this fashionable Korean influenced hairstyle. He looked like a college student working part time. On his chest a nametag spelled out his name, James. He smiled as he waited for my order.

I hardly came to coffee shops, so I had no idea what I wanted. Not bothering to think I asked him what he recommended.

Typically if one asked this the barista would answer the store's most expensive item, or the item with the most stocks and therefore needed disposing of. But I was surprised to get a follow up question: how was I feeling right now?

Well, I answered without thinking, my dog just died, and I asked him to give me something so I would feel better. Pleasantries.

But that was a decision I regretted when I found a seat on the corner of the coffee shop by the glass window. The name of Arabella Raut was a name of reclusion 
- a secret kept from the world, like a time capsule with which we could always remember the suffering, hidden to keep it stuck in the past. Down the decades we who had held the name avoided talking about the details of the miseries we performed - avoided talking in general. I had just hinted at my latest misery with that barista. Of all the holders of the name it seemed I was the one most prone to such slips.

But that was not much of a giveaway, I thought as I turned on my tablet. It was just a negligible slip, not too much betrayal of the past.

I drove the matter out of my mind by surfing the internet. Mindanao conflicts.

One recent incident caught my eye: a village on the outskirts of Talaingod was razed by Alamara, a government sponsored but violent lumad militia, just three days ago. I donated to the Salugpongan schools there, but had never actually been to Talaingod. This was a good opportunity.

The heir to all these miseries...

I'd done almost all of them for seven years now, and contributed two of my own. But there was actually one ritual left.

Arabella the Second (Najera) died after starving herself in her room for three months. Arabella the Fourth (Helena) hanged herself on that tree in Makilala. And Auntie Arabella the Sixth slit her throat. Their death certificates had their birth names, and their ashes were scattered in their hometowns.

James the barista served my order in a large mug. The froth at the top had been designed into an ornate chrysanthemum pattern.

Black tea latte, he said with the same smile. Usually they only used Keemun, he said, but he mixed in Ceylon from his own tea canister, and he made it a bit sweeter than usual. He said it was on him. Up close I realized how good he smelled.

He looked at me in the eye, and I saw in his eyes a look I had not seen for longer than I could remember. It was a living look, unlike Auntie Arabella's lifeless stare (or those of my own when I looked at myself in the mirror), a look that betrayed genuine presence, as if his eyes were saying it was his wish to be here, looking at me. It was like a radically more benign but no less ardent version of the looks thrown at me by all the men who had violated me - 
And I felt a jolt of shame shudder down my spine, and I ended the stare by looking at the mug. Without looking at him I thanked him timidly, and he went back to the counter. Occasionally I would catch him stealing glimpses at me.

The rain outside had made it cool enough that they did not need to bring the aircon down too low a temperature, and its soft pattering outside was only punctuated by the occasional vehicle. The cushioned seat I was on was warm and very snug. I sipped the tea, and its piping heat trickled gently down my throat, while the sweet froth was just warm and fluffy on my lips.

This was the first time I had felt palpable pleasure in almost a decade. I had forgotten what it was to feel good.

And then the jolt of shame filled me again - no, I could not accept this pleasure. Not in the face of all the legacy of suffering that I who held the name bore.

The life I lived led to a different end from the world's happiness...

And at the thought of that end, of burning myself in the middle of a dried corn field at this moment of comfort - all the loss I had borne with the name, all the collective devastation, all of it suddenly became more real than it ever was.

As I held the mug my hands trembled. The misery, oh the misery of it all.

The first Arabella Raut who had only began wondering about life, Lucrezia Segovia who left her young daughter and the world that adored her far too soon, Lola Laylania Mangadto who never saw her granddaughter grow up, all of them who bore the burden of living - no, who bore living as a burden - all of them who bore this name and suffered it, and who only knew suffering.

And Ate Ginamae, who would have gladly, gladly taken that burden...

And my tears began to fall, unsettling the chrysanthemum pattern on the froth in my mug. My tears, and the tears of a century and a decade of misery. None of the holders of the name ever cried, we had allowed the pain to let out our suffering, unwittingly dulling it for us. In our grief we had forgotten what we were grieving over.

Yes, I had to remember with tears. To live in memory of those who are gone was to live for those who are gone. What had been lost could not be more palpable if one lived in the now. I was Arabella Raut the Eighth and I grieved, but if I was to 
grieve for Ate Ginamae - and for all who had suffered her fate and perished - I had to be Gracelyn Balbuena.

Ate Ginamae... All my memories of her were of me embracing her - Every single moment of my life I loved her, I had never wasted a moment while I had her. And yet now, not even a lifetime of unwasted opportunities was enough to fill her absence. She was gone, they were all gone. And I who lived must live to feel the sheer cruelty oftheir absence.

Slowly, for the first time in a hundred and ten years, I began to sob. 